\title{
Internal Resources of Dairy Cattle Farming Business and Their Effects on Institutional Performance and Business Development
}

\author{
Amam $^{1,2}{ }^{2}$, Mochamad Wildan Jadmiko ${ }^{2}$, Pradipta Ayu Harsita ${ }^{2}$ and Roni Yulianto ${ }^{2}$ \\ ${ }^{1}$ Department of Agribusiness, Faculty of Agricultural, Jember University, Jember, East Java, Indonesia \\ ${ }^{2}$ Department of Animal Husbandry, Faculty of Agricultural, Jember University, Jember, East Java, Indonesia \\ *Corresponding author email: amam.faperta@unej.ac.id
}

\begin{abstract}
The purpose of this study was to identify the area mapping and internal resources of dairy cattle farming business and to assess their effects on institutional performance of the business risk aspects. The research was carried out at the National Dairy Cattle Area (KPSPN), Malang District, East Java Province, involving all 174 dairy cattle farmers/members of the Tirtasari Kresna Gemilang Business Group (KUB). The data were subject to PLS (Partial Least Square) analysis. The results showed that internal resources had an effect on institutional performance by $23.4 \%$, while business risk aspects were influenced by internal resources and institutional performance by $54.7 \%$. The institutional performance of dairy farmers in KUB Tirtasari Kresna Gemilang was influenced by the internal resources of dairy cattle business (23.3\%), while internal resources and institutional performance of dairy cattle farmers affected all together the development of livestock business by $54.6 \%$. The development of dairy cattle farming business was conducted by harnessing all potential resources, including institutional carrying capacity of farmers. Farmers' potential resources must be considered as their accessibility to resources also affected the business development.
\end{abstract}

Keywords: internal resources, financial, technological, physical, dairy cattle

Abstrak. Tujuan dari penelitian ini adalah untuk mengidentifikasi pemetaan area dan mengidentifikasi sumber daya internal bisnis peternakan sapi perah dan menilai pengaruhnya terhadap kinerja kelembagaan dari aspek resiko bisnis. Penelitian ini dilakukan di Kawasan Peternakan Sapi Perah Nasional (KPSPN), Kabupaten Malang, Provinsi Jawa Timur. Responden penelitian ini adalah semua peternak sapi perah yang menjadi anggota "Kelompok Usaha Bersama" (KUB/Kelompok Usaha) Tirtasari Kresna Gemilang yang berjumlah 174 orang. Data dianalisis menggunakan metode PLS (Partial Least Square). Hasil penelitian menunjukkan bahwa sumber daya internal berpengaruh pada kinerja kelembagaan sebesar $23,4 \%$, sedangkan aspek risiko bisnis dipengaruhi oleh sumber daya internal dan kinerja kelembagaan sebesar $54,7 \%$. Kinerja kelembagaan peternak sapi perah di KUB) Tirtasari Kresna Gemilang dipengaruhi oleh sumber daya internal bisnis peternakan sapi perah $(23,3 \%)$, sedangkan sumber daya internal dan kinerja kelembagaan peternak sapi perah mempengaruhi secara bersama-sama terhadap pengembangan bisnis peternakan seperti sebanyak $54,6 \%$. Pengembangan usaha peternakan sapi perah dilakukan dengan memanfaatkan semua sumber daya potensial yang tersedia. Kelembagaan daya dukung petani juga memiliki peran penting dalam pengembangan bisnis peternakan. Aksesibilitas petani ke sumber daya memiliki peran penting dalam pengembangan usaha peternakan sapi perah, sehingga pemanfaatan sumber daya potensial mereka harus dipertimbangkan.

Kata kunci: sumber daya internal, finansial, teknologi, fisik, sapi perah

\section{Introduction}

Efforts to develop livestock sub-sectors include establishing and structuring livestock areas through the agribusiness system approach. The development of commoditybased agribusiness areas is an alternative program that aims to answer the challenges and demands of development. The development of the livestock area is oriented towards increasing income and community welfare (Mukson et al., 2009).
The Minister of Agriculture of the Republic of Indonesia register number was 43/Ktps/PD.010/1 of 2015 in Malang District area is one of the dairy farming in Indonesia. Mandaka and Hutagaol (2005) stated that dairy cattle business faced various problems in the upstream, livestock farming (onfarm), and downstream sectors. Problems in the upstream sector include low livestock productivity, lack of availability of dairy cows, high cost of feed, the small scale of livestock ownership, and low 
quality of human resources for dairy farmers. The onfarm issues include low technical knowledge of cultivation and unrecord systems, decreasing the availability of feed for forages, shifting functions of agricultural land, low business capital, and lack of cooperation from various sectors. And the downstream problems are low selling prices of fresh milk and the unstable calf selling prices for dairy cattle.

Farmers' accessibility to resources can affect their Human Resource aspects (Amam et al., 2019a). The internal resources of livestock business consist of the accessible financial resources, technological resources, and physical resources (Amam et al., 2019b). The financial resources are the accessible resources of assets or business capital. Technology resources are the accessible resources for adoption, innovation, and technological implications, and physical resources include production facilities and infrastructure to support livestock business.

This study aimed to map the accessible internal resources by dairy farmers and their influence on the institutional performance of dairy farmers and livestock farming business development. Institutional performance and livestock farming business development could be affect to the cattle dairy of farmer HR (Amam and Harsita, 2019). The research hypothesis is that the internal resources of dairy cattle business influenced the institutional performance of dairy farmers and development of the dairy cattle business. As opposed to the current examination of livestock business development using the Location Quotient (LQ) and Analytical Hierarchy Process (AHP) approach, this research used the Structural Equation Modeling (SEM) approach with the Partial Least Square (PLS) method.

\section{Materials and Methods}

The study was conducted in Pujon Subdistrict, Malang District from May to June 2019. The research location was deliberately chosen to refer to the Minister of Republic of
Indonesia Decree of 2015 Number 43/Ktps/PD.010/1 concerning Determination of National Dairy Cattle Area (KPSPN). The research sample was all farmers belong to the Tirtasari Kresna Gemilang Business Group (KUB). KUB Tirtasari Kresna Gemilang is an institution for 174 dairy cattle of farmers in Pujon Sub-district. The KUB was established in 2017 and with a legal entity number 0010084AH.01.07. KUB Tirtasari Kresna Gemilang was selected as the object of the study because it refers to the Republic of Indonesia Government Regulation Number 6 in 2013 concerning Empowerment of Farmers. Amam and Soetriono (2019) stated that institutional performance had a positive effect on livestock business development.

The data were mainly collected using a 5scale likert questionnaire $(+1$ to +5$)$, as well as an interview and an observation to obtain additional information from dairy farmers. The collected data were analyzed using PLS (Partial Least Square) method with SmartPLS, which is useful for testing or strengthening weak theories and/or finding new theories (Wiyono, 2011).

Alfa et al. (2017) stated that SEM (Structural Equation Model) with PLS method was an alternative technique where the data may not be multivariate normal distributed. Jaya and Sumertajaya (2008) mentioned that the modeling steps in structural equations with the PLS method include 1) design a structural model or inner model; 2) design a measurement model or outer model; 3) construct a path diagram; 4) convert path diagrams to system equations; 5) estimation; 6) goodness of fit; and 7) hypothesis testing.

The main variables of the study consist of financial resources, technological resources, physical resources, institutional performance, and development of dairy cattle business. Table 1 describes these variables as well as the structural equation modelling that illustrates the relationships between variables and 
indicators. Illustrations of modeling in structural equations that explain the relationships between variables and indicators described in Table 1 in the PLS SEM model are shown in Figure 1.

The notation in Figure 1 shows that $\xi$ is an exogenous latent variable, $\eta$ is an exogenous latent variable, $\lambda$ is loading latent variable factors (exogenous and endogen), $\beta$ is the coefficient of influence of endogenous variables, coefficient of influence of exogenous variables on endogenous variables, $\zeta$ is a model error, $\delta$ is a measurement error on the manifest variable for the exogenous latent variable, and $\varepsilon$ is a measurement error in the manifest variable for the exogenous latent variable.

Table 1. Research variables and indicators

\begin{tabular}{|c|c|}
\hline Variables & Variables \\
\hline Financial Resources $\left(\mathrm{X}_{1}\right)$ & $\begin{array}{l}\text { Main income }\left(X_{1.1}\right) \\
\text { Income from dairy cattle business }\left(X_{1.2}\right) \\
\text { Income from businesses other than livestock }\left(X_{1.3}\right) \\
\text { Revenues from other livestock businesses }\left(X_{1.4}\right) \\
\text { Total income for daily living needs }\left(X_{1.5}\right) \\
\text { Amount of savings }\left(X_{1.6}\right) \\
\text { Amount of debt }\left(X_{1.7}\right) \\
\text { Repayment of debt }\left(X_{1.8}\right) \\
\text { Ownership of Calf Cow }\left(X_{1.9}\right) \\
\text { Ownership of heifers }\left(X_{1.10}\right) \\
\text { Ownership of Pregnant Cows }\left(X_{1.11}\right) \\
\text { Ownership of Cattle Production }\left(X_{1.12}\right) \\
\text { Ownership Dry Cattle Period }\left(X_{1.13}\right) \\
\text { Total population of cattle raised }\left(X_{1.14}\right)\end{array}$ \\
\hline Technology Resources $\left(X_{2}\right)$ & $\begin{array}{l}\text { Selection of broodstock / seedlings }\left(X_{2.1}\right) \\
\text { Feed technology }\left(X_{2.2}\right) \\
\text { Animal health }\left(X_{2.3}\right) \\
\text { Housing }\left(X_{2.4}\right) \\
\text { Marketing of milk }\left(X_{2.5}\right) \\
\text { Technology for increasing milk production }\left(X_{2.6}\right)\end{array}$ \\
\hline Physical Resources $\left(\mathrm{X}_{3}\right)$ & $\begin{array}{l}\text { Houses of residence }\left(X_{3.1}\right) \\
\text { Cowshed }\left(X_{3.2}\right) \\
\text { Means of transportation }\left(X_{3.3}\right) \\
\text { Communication facilities }\left(X_{3.4}\right) \\
\text { Means of information }\left(X_{3.5}\right) \\
\text { Electricity used }\left(X_{3.6}\right) \\
\text { Land tenure }\left(X_{3.7}\right) \\
\text { Land used }\left(X_{3.8}\right) \\
\text { Availability of water sources }\left(X_{3.9}\right) \\
\text { Availability of feed sources }\left(X_{3.10}\right) \\
\end{array}$ \\
\hline Institutional Performance $\left(Z_{1}\right)$ & $\begin{array}{l}\text { Means of livestock groups }\left(\mathrm{Z}_{1.1}\right) \\
\text { Achievement of group goals }\left(\mathrm{Z}_{1.2}\right) \\
\text { Group functions and tasks }\left(\mathrm{Z}_{1.3}\right) \\
\text { Group structure }\left(\mathrm{Z}_{1.4}\right) \\
\text { Group harmony }\left(\mathrm{Z}_{1.5}\right) \\
\text { Institutional form }\left(\mathrm{Z}_{1.6}\right)\end{array}$ \\
\hline $\begin{array}{l}\text { Development of Livestock } \\
\text { Business }\left(Y_{1}\right)\end{array}$ & $\begin{array}{l}\text { Increased income }\left(\mathrm{Y}_{1.1}\right) \\
\text { Increased livestock population maintain }\left(\mathrm{Y}_{1.2}\right) \\
\text { Increase in the number of workers paid }\left(\mathrm{Y}_{1.3}\right) \\
\text { Increased production unit / enclosure }\left(\mathrm{Y}_{1.4}\right)\end{array}$ \\
\hline
\end{tabular}




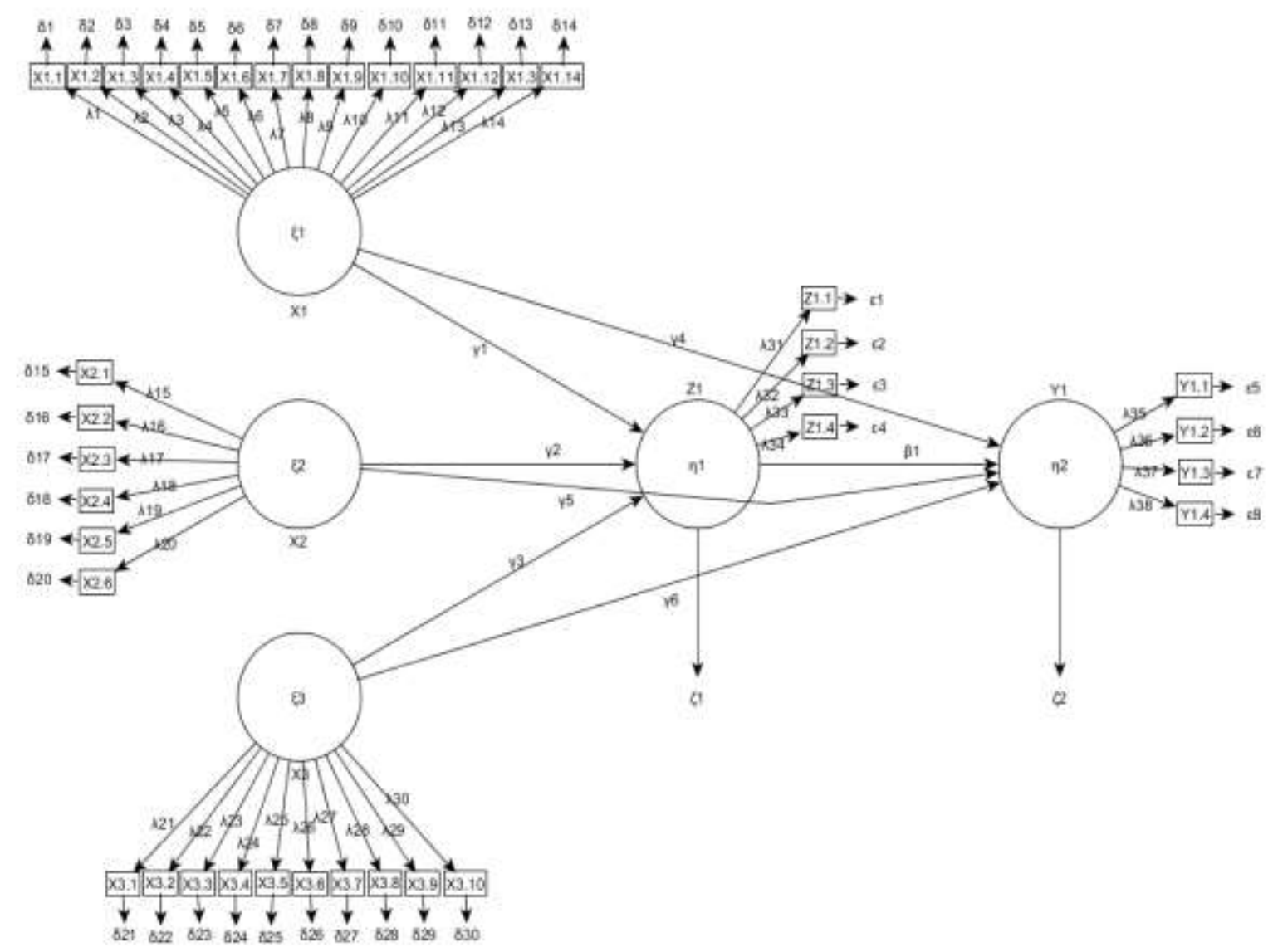

Figure 1. Framework of research model

The outer model value is the specification of the relationship between the latent variable and the indicator or it defines the characteristics of the construct with its manifest variable. Abdillah and Jogiyanto (2015) stated that the reflective model assumes that all indicators are influenced by latent variables (constructs), so that inter-indicators require correlations with one another, while the formative model assumes that inter-indicators are uncorrelated. The mathematical reflective and formative indicator models are as follows:

$\mathrm{x}=\Lambda x \xi+\delta$ dan $\mathrm{y}=\Lambda \mathrm{y} \eta+\varepsilon$

$\xi=\Pi_{\xi} X+\delta$ dan $\eta=\Pi \eta Y+\varepsilon$

The substitution of mathematical equations in this study by application based on the model Figure 1.

Exogenous latent variable (X1) / reflective

$$
\begin{aligned}
& \mathrm{X}_{1.1}=\left(\lambda_{1} \xi_{1}\right)+\delta_{1} \\
& \mathrm{X}_{1.2}=\left(\lambda_{2} \xi_{1}\right)+\delta_{2} \\
& \mathrm{X}_{1.3}=\left(\lambda_{3} \xi_{1}\right)+\delta_{3}
\end{aligned}
$$

$$
\begin{aligned}
\mathrm{X}_{1.4} & =\left(\lambda_{4} \xi_{1}\right)+\delta_{4} \\
\mathrm{X}_{1.6} & =\left(\lambda_{6} \xi_{1}\right)+\delta_{6} \\
\mathrm{X}_{1.7} & =\left(\lambda_{7} \xi_{1}\right)+\delta_{7} \\
\mathrm{X}_{1.8} & =\left(\lambda_{8} \xi_{1}\right)+\delta_{8} \\
\mathrm{X}_{1.9} & =\left(\lambda_{9} \xi_{1}\right)+\delta_{9} \\
\mathrm{X}_{1.11} & =\left(\lambda_{11} \xi_{1}\right)+\delta_{11} \\
\mathrm{X}_{1.12} & =\left(\lambda_{12} \xi_{1}\right)+\delta_{12} \\
\mathrm{X}_{1.13} & =\left(\lambda_{13} \xi_{1}\right)+\delta_{13} \\
\mathrm{X}_{1.14} & =\left(\lambda_{14} \xi_{1}\right)+\delta_{14}
\end{aligned}
$$

Exogenous latent variable (X2) / reflective

$$
\begin{aligned}
& \mathrm{X}_{2.1}=\left(\lambda_{15} \xi_{2}\right)+\delta_{15} \\
& \mathrm{X}_{2.2}=\left(\lambda_{16} \xi_{2}\right)+\delta_{16} \\
& \mathrm{X}_{2.4}=\left(\lambda_{18} \xi_{2}\right)+\delta_{18} \\
& \mathrm{X}_{2.5}=\left(\lambda_{19} \xi_{2}\right)+\delta_{19} \\
& \mathrm{X}_{2.6}=\left(\lambda_{20} \xi_{2}\right)+\delta_{20}
\end{aligned}
$$

Exogenous latent variable $(\mathrm{X} 3)$ / reflective

$$
\begin{aligned}
& X_{3.1}=\left(\lambda_{21} \xi_{3}\right)+\delta_{21} \\
& X_{3.2}=\left(\lambda_{22} \xi_{3}\right)+\delta_{22} \\
& X_{3.3}=\left(\lambda_{23} \xi_{3}\right)+\delta_{23} \\
& X_{3.4}=\left(\lambda_{24} \xi_{3}\right)+\delta_{24} \\
& X_{3.6}=\left(\lambda_{26} \xi_{3}\right)+\delta_{26} \\
& X_{3.7}=\left(\lambda_{27} \xi_{3}\right)+\delta_{27} \\
& X_{3.8}=\left(\lambda_{28} \xi_{3}\right)+\delta_{28} \\
& X_{3.9}=\left(\lambda_{29} \xi_{3}\right)+\delta_{29} \\
& X_{3.10}=\left(\lambda_{30} \xi_{3}\right)+\delta_{30}
\end{aligned}
$$


Exogenous latent variable $\left(\mathrm{Z}_{1}\right) /$ reflective

$$
\begin{aligned}
& Z_{1.1}=\left(\lambda_{31} \eta_{1}\right)+\varepsilon_{1} \\
& Z_{1.2}=\left(\lambda_{32} \eta_{1}\right)+\varepsilon_{2} \\
& Z_{1.3}=\left(\lambda_{33} \eta_{1}\right)+\varepsilon_{3} \\
& Z_{1.4}=\left(\lambda_{34} \eta_{1}\right)+\varepsilon_{4}
\end{aligned}
$$

Exogenous latent variable (Y1)/reflective

$$
\begin{aligned}
& \mathrm{Y}_{1.1}=\left(\lambda_{35} \eta_{2}\right)+\varepsilon_{5} \\
& \mathrm{Y}_{1.2}=\left(\lambda_{36} \eta_{2}\right)+\varepsilon_{6} \\
& \mathrm{Y}_{1.3}=\left(\lambda_{37} \eta_{2}\right)+\varepsilon_{7} \\
& \mathrm{Y}_{1.4}=\left(\lambda_{38} \eta_{2}\right)+\varepsilon_{8}
\end{aligned}
$$

Exogenous latent variable (Z1)/ formative

$$
\eta_{1}=\left(\left(\eta_{1} \gamma_{1}+\eta_{1} \gamma_{2}+\eta_{1} \gamma_{3}\right)+\varepsilon\right.
$$

Exogenous latent variable (Y1)/formative

$$
\eta_{2}=\left(\left(\eta_{2} \gamma_{1}+\eta_{2} \gamma_{2}+\eta_{2} \gamma_{3}+\eta_{2} \beta_{1}\right)+\varepsilon\right.
$$

The inner model value design of the structural model of relations between latent variables based on the formulation of the problem (Jaya and Sumertajaya, 2008). The inner equation of the model mathematically based on the model in Figure 1.

Exogenous latent variable (X1) / reflective:

$\eta_{1}=\lambda_{1} \xi_{1}+\lambda_{2} \xi_{2}+\lambda_{3} \xi_{3}+\varsigma_{1}$

$\eta_{2}=\beta_{1} \eta_{1}+\lambda_{4} \xi_{1}+\lambda_{5} \xi_{2}+\lambda_{6} \xi_{3}+\varsigma_{2}$

Test of the SEM model with PLS and the testing criteria according to Wiyono (2011) described in Table 2.

\section{Results and Discussion}

\section{Outer Model}

Testing the indicators of various variables aimed to measure an occurring condition indirectly. The variables in this study $\mathrm{X} 1, \mathrm{X} 2, \mathrm{X} 3$, $\mathrm{Z1}$, and $\mathrm{Y} 1$. The indicators on a variable are considered valid if they meet the requirements, i.e. an outer loading value of at least 0.500 . Therefore, outer loading below 0.500 are invalid and do not meet the requirements. The PLS results on indicators are shown in Table 3.

The results of indicators in Table 3 after eliminating invalid indicators and the results of PLS modeling that are formed are in Figure 2.

The criteria of various tests on outer model using PLS method include the values of AVE (Average Variance Extracted), CR (Composite Reliability), R Square (R2), CA (Cronbach's Alpha), communality, and redundancy. The results of various criteria testing are shown in Table 4. The structural testing model with a statistical $t$ value $(1,653)$ in the form of the PLS bootstrapping is shown in Figure 3.

The institutional performance of dairy farmers at KUB (Business Group) Tirtasari Kresna Gemilang affected the internal resources of dairy cattle business by $23.3 \%$, while internal resources and institutional

\begin{tabular}{|c|c|c|}
\hline Model Test & Output PLS & Criteria \\
\hline $\begin{array}{l}\text { Test Indicator } \\
\text { (Outer Model) }\end{array}$ & $\begin{array}{l}\text { 1. Convergent Validity } \\
\text { 2. Discriminant Validity } \\
\text { 3. Average Variance Extracted } \\
\text { (AVE) } \\
\text { 4. Composite Reliability (CR) }\end{array}$ & $\begin{array}{l}\text { 1. The minimum value of loading factors } 0,50 \text { - } \\
0,60 \\
\text { 2. The value of cross loading correlation with its } \\
\text { latent variables must be greater than the } \\
\text { correlation with other latent variables } \\
\text { 3. The value of } A V E>0,50 \\
\text { 4. Better } \geq 0,70\end{array}$ \\
\hline $\begin{array}{l}\text { Test of } \\
\text { influence } \\
\text { (Inner Model) }\end{array}$ & $\begin{array}{l}\text { 1. Coefficient of Determination } \\
\left(R^{2}\right) \\
\text { 2. Coeficient of Parameter } \\
\text { 3. t-statistic }\end{array}$ & $\begin{array}{l}\text { 1. Endogenous latent variable } 0.67 \text { (strong); } \\
0.33 \text { (moderate); and } 0.19 \text { (weak). } \\
\text { 2. Significant structural models, through the } \\
\text { bootstrapping method. }\end{array}$ \\
\hline
\end{tabular}
performance of dairy farmers affected the development of livestock farming business by $54.6 \%$. Amam and Soetriono (2019) stated that the role of institutions is doesn't preventive actions for farmers to minimize business risks, also to livestock farming business development as effort to support the welfare of the community.

Table 2. Test of the PLS SEM model and its criteria

Resource: Wiyono (2011) 
Amam et al. /Animal Production. 21(3):157-166, 2019

Accredited by Kemenristek Dikti No 32a/E/KPT/2017. ISSN 1411-2027

Table 3. Indicator of test results

\begin{tabular}{cccc}
\hline Variable & Indicator & Value of Outer Loading & Explanation \\
\hline $\mathrm{X} 1$ & $\mathrm{X}_{1.1}$ & 0.723 & valid \\
& $\mathrm{X}_{1.5}$ & 0.648 & valid \\
& $\mathrm{X}_{1.9}$ & 0.602 & valid \\
& $\mathrm{X}_{1.10}$ & 0.653 & valid \\
& $\mathrm{X}_{1.11}$ & 0.861 & valid \\
& $\mathrm{X}_{1.12}$ & 0.734 & valid \\
& $\mathrm{X}_{1.13}$ & 0.737 & valid \\
& $\mathrm{X}_{1.14}$ & 0.840 & valid \\
\hline $\mathrm{X} 2$ & $\mathrm{X}_{2.1}$ & 0.785 & valid \\
& $\mathrm{X}_{2.2}$ & 0.629 & valid \\
& $\mathrm{X}_{2.4}$ & 0.635 & valid \\
& $\mathrm{X}_{2.6}$ & 0.668 & valid \\
\hline $\mathrm{X} 3$ & $\mathrm{X}_{3.4}$ & 0.941 & valid \\
& $\mathrm{X}_{3.5}$ & 0.818 & valid \\
\hline $\mathrm{Z1}$ & $\mathrm{Z}_{1.1}$ & 0.623 & valid \\
& $\mathrm{Z}_{1.2}$ & 0.788 & valid \\
& $\mathrm{Z}_{1.3}$ & 0.837 & valid \\
& $\mathrm{Z}_{1.4}$ & 0.750 & valid \\
\hline $\mathrm{Y} 1$ & $\mathrm{Y}_{1.1}$ & 0.847 & valid \\
& $\mathrm{Y}_{1.2}$ & 0.873 & valid \\
& $\mathrm{Y}_{1.3}$ & 0.490 & valid \\
\hline
\end{tabular}

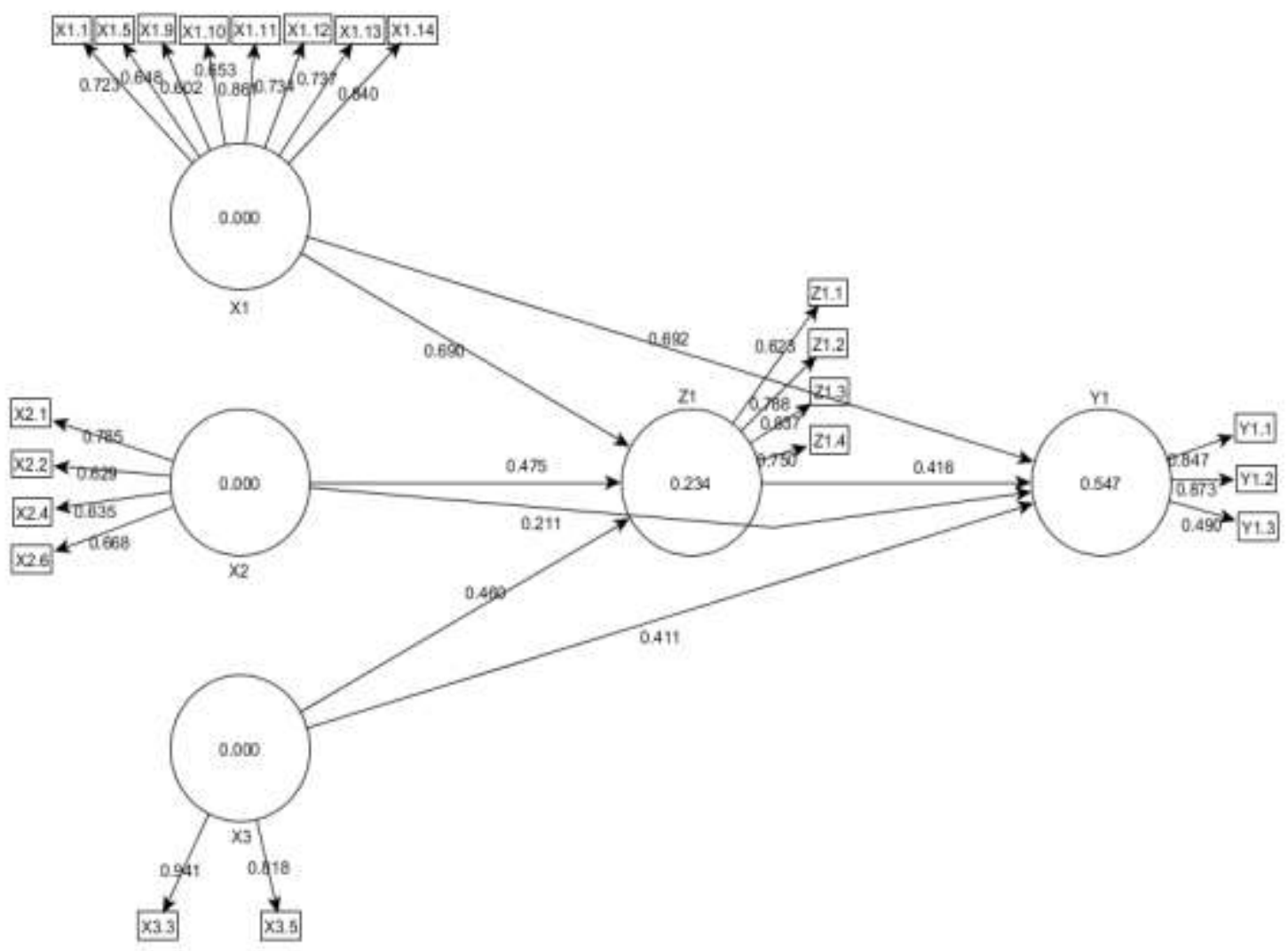

Figure 2. Logs of PLS results 
Table 4. Quality Criteria with PLS Method

\begin{tabular}{ccccccc}
\hline Variable & AVE & CR & $\mathrm{R}^{2}$ & CA & Communality & Redudancy \\
\hline X1 & 0.632 & 0.899 & & 0.871 & 0.632 & \\
X2 & 0.536 & 0.752 & & 0.674 & 0.536 & \\
X3 & 0.776 & 0.873 & & 0.728 & 0.776 & \\
Z1 & 0.667 & 0.838 & 0.233 & 0.743 & 0.667 & 0.274 \\
Y1 & 0.673 & 0.792 & 0.546 & 0.693 & 0.673 & 0.292 \\
\hline
\end{tabular}

Table 5. Total Effect

\begin{tabular}{cccccc}
\hline Influence Test & Original Sample & $\mathrm{M}$ & STDEV & STERR & t statistic \\
\hline $\mathrm{X} 1 \rightarrow \mathrm{Z1}$ & 0.690 & 0.674 & 0.121 & 0.121 & 2.623 \\
$\mathrm{X} 2 \rightarrow \mathrm{Z1}$ & 0.475 & 0.472 & 0.103 & 0.103 & 4.597 \\
$\mathrm{X} 3 \rightarrow \mathrm{Z1}$ & 0.460 & 0.463 & 0.125 & 0.125 & 3.414 \\
$\mathrm{X} 1 \rightarrow \mathrm{Y} 1$ & 0.692 & 0.698 & 0.058 & 0.058 & 12.031 \\
$\mathrm{X} 2 \rightarrow \mathrm{Y} 1$ & 0.211 & 0.217 & 0.078 & 0.078 & 7.098 \\
$\mathrm{X} 3 \rightarrow \mathrm{Y} 1$ & 0.411 & 0.406 & 0.083 & 0.083 & 7.505 \\
$\mathrm{Z} 1 \rightarrow \mathrm{Y} 1$ & 0.416 & 0.422 & 0.079 & 0.079 & 4.185 \\
\hline
\end{tabular}

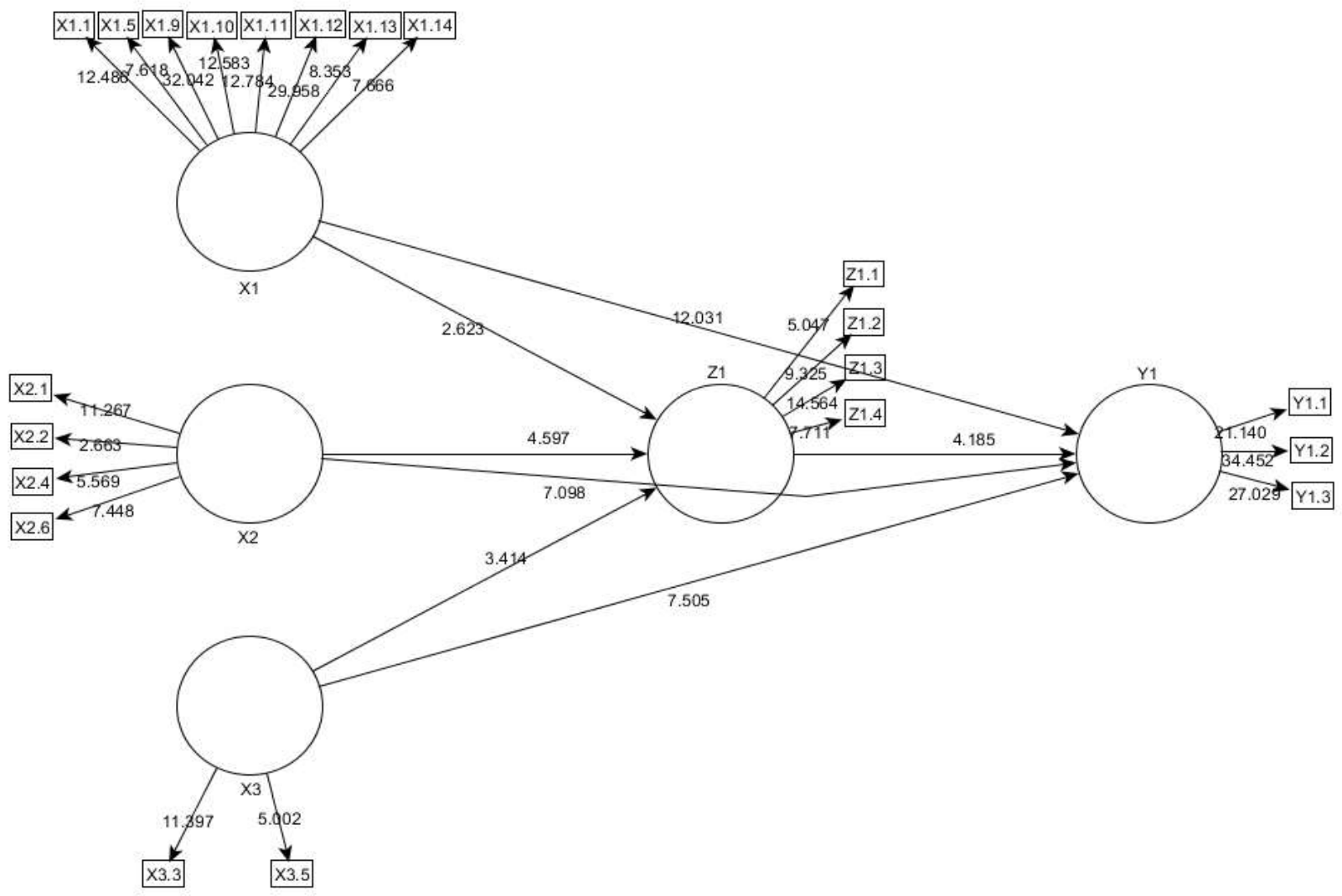

Figure 3. Results of PLS Bootstrapping

\section{Effect of Internal Resources on the Institutional Performance of Dairy Farmers}

The relationship of financial resources with the institutional performance of dairy farmers was significant with $t$ value of 2,623. The Original Sample Estimate gave positive impact (0.690) which indicates a positive direction of relationship between financial resources and the institutional performance of dairy farmers. It means that the financial resources accessible by farmers at the KUB Tirtasari Kresna Gemilang affected the institutional performance of dairy farmers. Mauludin et al. (2017) stated that the production strength in 
each period of dairy cattle, land, and farmer skills.

The relationship of technology resources with the institutional performance of dairy farmers was significant with a t-statistic of 4,597. The value of Original Estimate Sample was positive $(0.475)$ which indicates a positive impact of the relationship direction between technological resources and institutional performance of dairy farmers. The technological resources accessible by farmers at KUB Tirtasari Kresna Gemilang affected the institutional performance of dairy cattle farmers. Matondang et al. (2012) stated that the center of dairy cattle population is concentrated in Java Island (99\%). Despite the food supply and limited land resources, the technology for developing dairy cattle farming businesses outside Java needs to be supported given the strength factors such as the market potential of fresh milk climate suitability, and fibrous feed sources available.

The relationship of physical resources of institutional performance of dairy cattle farmer was significant with $t$ value of 3.414 . The original sample estimate value gave positive impact $(0.460)$ which indicates the direction of the relationship between physical resources and the institutional performance of dairy cattle farmers. The physical resources accessible by farmers at the KUB Tirtasari Kresna Gemilang and gave affect to the institutional performance of dairy cattle farmers. Anggraini and Putra (2017) stated that livestock ownership illustrates origin of the capital owned by farmer in their business.

\section{Effect of Internal Resources on the Development of Livestock Business}

The relationship of financial resources with livestock business development is significant with a statistical $t$ value of 12,031 . The Original Sample Estimate value is positive $(0.692)$ which indicates the positive direction of the relationship between financial resources and the development of livestock business. It means that the financial resources that can be accessed by farmers at the KUB Tirtasari Kresna Gemilang affected the development of livestock businesses. Rianzani et al. (2018) state that one of the priority strategies that can be used for development and sustainability of dairy cattle farming to increase capital making loans to banks with aim of increasing scale of the livestock business.

The relationship of technological resources with livestock business development was significant with $t$ value 7.096. The Original Sample Estimate value is positive (0.211) which indicates that the direction of the relationship between technological resources and development business gave positive impact. It means that technological resources could be accessed by farmers at the KUB Tirtasari Kresna Gemilang affect to the development of livestock businesses. Poetri et al. (2014) state that waste has an impact on the environment.

The relationship between physical resources and livestock development business was significant with t-value 7.505. The Original Sample Estimate value was positive impact 0.411 which indicates the direction of the relationship between physical resources and development of livestock business. This means that the physical resources that can be accessed by farmers at the KUB Tirtasari Kresna Gemilang affect to the development of livestock businesses. Physically, the sustainability indicator in economic dimension has an average category. It means that dairy cattle business is not too conducive to create a highly competitive agribusiness system respond to the market dynamics effectively and efficiently (Sutanto and Hendraningsih, 2011).

\section{Relationship between Institutional Performance and Livestock Development Business}

The relationship between institutional performance and livestock development business is significant with a statistical $t$ value of 4.185. The Original Sample Estimate value was 
0.416 which indicates that the direction of the relationship between institutional performance and livestock development business gave positive impact. It means that institutional performance at KUB Tirtasari Kresna Gemilang influences to the development of livestock business. Santosa et al. (2013) stated that the population enhancement of dairy cattle could be done in the region supported by the potential of its own region for development of dairy cattle business. The potential for dairy cattle enhancement could be done through the provider's availability, human resource knowledge, milk demand, income from the farmer, market infrastructure, loan institutions, and local government policies.

Barokah (2009) states that one of the alternative strategies for developing dairy farming business and optimize the role of institutions to improve the management of dairy cattle by farmer management of procurement, management of seedlings, production facilities, and product diversification. Elida (2016) stated that the potential for developing dairy cows could be improved by the availability of feed, knowledge of farmers, demand for milk, farmers' income, market infrastructure, the role of institutions, and government policies.

\section{Conclusions}

The institutional performance of dairy farmers in KUB (Business Group) Tirtasari Kresna Gemilang was influenced by the internal resources of dairy cattle business (23.3\%), while internal resources and institutional performance of dairy cattle farmers affected all together the development of livestock business by $54.6 \%$. Development of dairy cattle farming business is carried out by utilizing all the potentially available resources. Institutional carrying capacity of farmers also has an important role in the development of livestock farming business. Farmers' accessibility to resources is important to develop dairy farming businesses, so utilizing their potential resources has to be considered.

\section{Acknowledgement}

The research project involved many parties who performed proper functions, duties, and responsibilities properly. The authors respectfully expressed their gratitude to 1 ) LP2M University of Jember (UNEJ); 2) KeRis (Research Group) IFSLR (Integrated Farming System for Large Ruminant); 3) KeRis SOSEKTHT (Research group of socio-economic aspects of Livestock Farming and Product Technology); 4) KUB (Business Group) Tirtasari Kresna Gemilang; and 5) Department of Animal Husbandry, Faculty of Agriculture, University of Jember.

\section{References}

Alfa, A. A. G., Rachmatin, D., dan Agustina, F. 2017. Analisis pengaruh faktor keputusan konsumen dengan structural equation modelling partial least square. Eurekamatika 5 (2): 59-71.

Abdillah, W. dan Jogiyanto. 2015. Partial Least Square (PLS) Alternatif Struktural Modelling (SEM) dalam Penelitian Bisnis. $I^{\text {st }}$ Edn. Andi Publisher. Yogyakarta.

Amam, M. W. Jadmiko, P. A. Harsita, dan M. S. Poerwoko. 2019 . Model pengembangan usaha ternak sapi perah berdasarkan aksesibilitas sumber daya. Jurnal Sain Peternakan Indonesia 14 (1): 61-69.

Amam, M. W. Jadmiko, P. A. Harsita, N. Widodo, dan M. S. Poerwoko. 2019 . Sumber daya internal peternak sapi perah dan pengaruhnya terhadap dinamika kelompok dan konteks kerentanan. Jurnal IImiah Peternakan Terpadu 7 (1): 192-200.

Amam dan P. A. Harsita. 2019. Efek domino performa kelembagaan, aspek risiko bisnis, dan pengembangan usaha terhadap SDM peternak sapi perah. Sains Peternakan 17 (1): 5-11.

Amam dan Soetriono. 2019. Evaluasi performa kelembagaan peternak sapi perah berdasarkan aspek risiko bisnis dan pengembangan usaha. Jurnal Ilmu dan Teknologi Peternakan Tropis 5 (8): 8-13.

Anggraini, N. dan R. A. Putra. 2017. Analisis Potensi Wilayah dalam Pengembangan Peternakan Sapi Potong di Kecamatan Sijunjung Kabupaten Sijunjung. Jurnal Agrifo 2 (2): 82-100. 
Barokah, U. 2009. Strategi Pengembangan Usaha Peternakan Sapi Perah Rakyat di Kabupaten Boyolali. Sains Peternakan 7 (2): 80-86.

Elida, S. 2016. Potensi dan Strategi Pengembangan Usaha Ternak Sapi Perah di Kecamatan Pangkalan Kerinci Kabupaten Pelalawan. Gontor Agrotech Science Journal 2 (2): 53-70.

Mandaka, S. dan M. P. Hutagaol. 2005. Analisis fungsi keuntungan, efisiensi ekonomi dan kemungkinan skema kredit bagi pengembangan skala usaha peternakan sapi perah rakyat di Kelurahan Kebon Pedes, Kota Bogor. Jurnal Agro Ekonomi 23: 191-208.

Matondang, R. H., C. Talib, and T. Herawati. 2012. Prospek Pengembangan Sapi Perah di Luar Pulau Jawa Mendukung Swasembada Susu di Indonesia. Wartazoa 22 (4): 161-168.

Mauludin, M. A., S. Alim, dan V. P. Sari. 2017. Pengembangan dan Dinamika Moda Produksi Usaha Peternakan Sapi Perah di Pangalengan Jawa Barat. Sosiohumaniora 19 (1): 37-44.

Mukson, T. Ekowati, M. Handayani, dan D. W. Harjanti. 2009. Faktor-faktor yang mempengaruhi kinerja usaha ternak sapi perah rakyat di Kecamatan Getasan Kabupaten Semarang. Dalam: Prosiding Seminar Nasional Kebangkitan Peternakan. Magister IImu Ternak. Semarang 20 Mei 2009. Fakultas Peternakan Universitas Diponegoro. Hal: 25-37.
Jaya, I. G. N. M. dan Sumertajaya, I. M. 2008. Pemodelan persamaan struktural dengan partial least square. Dalam: Seminar Nasional Matematika dan Pendidikan Matematika. Yogyakarta 28 November 2008. Jurusan Pendidikan Matematika FMIPA Universitas Negeri Yogyakarta. Hal: 118-132.

Poetri, N. A., A. Basith, N. H. Wijaya. 2014. Analisis Kelayakan Pengembangan Usaha Peternakan Sapi Perah KUNAK (Studi Kasus Usaha Ternak Kavling 176, Desa Pamijahan Kab. Bogor). Jurnal Manajemen dan Organisasi 5 (2): 122-138.

Rianzani, C., E. Kasymir, dan M. I. Affandi. 2018. Strategi Pengembangan Usaha Ternak Sapi Perah Kelompok Tani Neang Mukti di Kecamatan Air Naningan Kabupaten Tanggamus. Jurnal IImuIlmu Agribisnis 6 (2): 179-186.

Santosa, S. I., A. Setiadi., and R. Wulandari. 2013. Analisis Potensi Pengembangan Usaha Peternakan Sapi Perah dengan Menggunakan Paradigma Agribisnis di Kec. Musuk Kabupaten Boyolali. Buletin Peterakan 37 (2): 125-135.

Sutanto, A. dan L. Hendraningsih. 2011. Analisis Keberlanjutan Usaha Sapi Perah di Kecamatan Ngantang Kabupaten Malang. Gamma 7 (1): 1-12.

Wiyono, G. 2011. Merancang Penelitian Bisnis dengan Alat Analisis SPSS 17.0 \& Smart PLS 2.0. Penerbit: Unit Penerbit dan Percetakan STIM YKPN Yogyakarta. Yogyakarta. 